\title{
Within-reef differences in diet and body condition of coral-feeding butterflyfishes (Chaetodontidae)
}

\author{
Michael L. Berumen ${ }^{1,2, *}$, Morgan S. Pratchett ${ }^{2}$, Mark I. McCormick ${ }^{2}$ \\ ${ }^{1}$ Honors College, University of Arkansas, Fayetteville, Arkansas 72701, USA \\ ${ }^{2}$ Centre for Coral Reef Biodiversity, School of Marine Biology and Aquaculture, James Cook University of North Queensland, \\ Townsville, Queensland 4811, Australia
}

\begin{abstract}
Given the highly stochastic nature of larval supply, coral reef fishes often settle in suboptimal habitats with limited access to prey or other resources. Variation in the availability and quality of resources among different reef habitats is likely to have significant effects on the physiological condition and subsequent fitness of resident fishes, if not their absolute abundance. This study compared the abundance, feeding and condition of 2 species of coral-feeding butterflyfishes (Chaetodon baronessa and C. lunulatus) across contrasting habitats with markedly different prey availability. Despite differences in prey availability, densities of C. baronessa and C. lunulatus were very similar between locations. However, there was significant spatial variation in their feeding and physiological condition. In front-reef locations, where coral prey was highly abundant, C. baronessa fed preferentially and almost exclusively on the coral Acropora hyacinthus. In contrast, in back-reef locations where coral prey was scarce and A. hyacinthus lacking, C. baronessa was much less selective and consumed a wider range of coral prey. $C$. lunulatus was less selective than $C$. baronessa, but the diet of $C$. lunulatus also differed significantly between habitats. C. lunulatus consumed mostly A. hyacinthus in front-reef locations but not in greater proportions than it was available. In back-reef locations, C. lunulatus preferentially consumed A. intermedia and Porites spp. The physiological condition of both $C$. baronessa and $C$. lunulatus was much worse in back-reef locations compared to front-reef locations, which may reflect differences in the quantity and/or quality of prey available in different habitats. This study suggests that small-scale (within-reef) differences in prey availability can have significant effects on the physiological condition and subsequent fitness of coral reef fishes.
\end{abstract}

KEY WORDS: Competition - Coral reef fish · Feeding preferences - Hepatocyte vacuolation · Physiological body condition · Prey selection

\section{INTRODUCTION}

The distribution and abundance of coral reef fishes is ultimately dependent on the distribution and abundance of larvae at the time of settlement, which is known to be highly variable (e.g. Sale 1977, Doherty \& Williams 1988, Hixon \& Carr 1997). As a consequence, reef fish may be distributed across a wide range of habitat types with differing levels of shelter, prey availability, competition and/or predation. At all but very small spatial scales $(<1 \mathrm{~km})$, post-settlement reef fish have limited opportunity to choose among different habitats and are largely restricted to the habitat in which they settle (Jones 1991). In instances where reef fish settle in highly unfavourable habitats (e.g. habitats with limited resources and/or very high levels of predation), rates of early post-settlement mortality are likely to be very high (Levin 1998). Habitat variability has been shown to exert a major influence on the distribution, abundance and community structure of coral reef fishes (e.g. Shulman 1985, Munday et al. 1997, Holbrook et al. 2000). Even where reef fish do persist, there may be considerable variation in their physiological condition, growth, reproductive output and/or longevity associated with differences in the structure and composition of different reef habitats (Jones \& McCormick 2002). However, very few studies (Holbrook \& Schmitt 1986, Munday 2001) have considered 
ecological or fitness consequences for fishes living in different reef habitats.

Habitat requirements of coral reef fishes vary greatly among species, but most reef fish are closely associated with the spatial structure of reef substrata and particularly the abundance of scleractinian coral (Bell \& Galzin 1984, Munday et al. 1997, Holbrook et al. 2000), and/or the diversity of corals (Chabanet et al. 1997, Cadoret et al. 1999). Such associations arise because scleractinian corals are fundamental in providing living space and shelter for coral reef fishes (Holbrook et al. 2000, Syms \& Jones 2000). For butterflyfishes of the genus Chaetodon (family Chaetodontidae), scleractinian corals also represent an important food source (e.g. Anderson et al. 1981). Not surprisingly, associations between Chaetodon butterflyfishes and scleractinian corals are much stronger than for most other reef fishes. Both local and regional scale patterns in the abundance of butterflyfishes have been related to variation in live coral cover (Birkeland \& Neudecker 1981, Bouchon-Navaro et al. 1985, Findley \& Findley 1985, Bouchon-Navaro \& Bouchon 1989, Cadoret et al. 1999; but see also Bell et al. 1985, Fowler 1990). Moreover, several studies (e.g. Bouchon-Navaro et al. 1985, Williams 1986) have revealed significant declines in the abundance of butterflyfishes following extensive depletion of scleractinian corals, caused by outbreaks of crown-of-thorns starfish (see also Sano et al. 1984, 1987).

The aim of this study was to explore ecological and fitness consequences for coral-feeding butterflyfishes living across different reef habitats with marked differences in coral cover. In particular, we wanted to test whether the abundance, feeding rate or physiological condition is higher for butterflyfishes living in reef habitats with high coral abundance compared to butterflyfishes living in habitats with low coral abundance. Given their strong reliance on scleractinian corals (for food and shelter), variation in the abundance of scleractinian corals would be expected to affect not only the abundance of Chaetodon butterflyfishes, but also their physiological condition and individual fitness. Food availability has major effects on growth, maturation and reproductive output in a wide variety of fishes (e.g. Green \& McCormick 1999, McCormick 2003). Both abundance and composition of scleractinian corals varies greatly within and between coral reefs. Most striking are differences in the abundance (and composition) of scleractinian corals associated with cross-reef gradients in exposure (Done 1982). This study measured within-reef variation in the abundance, feeding habits and physiological condition of Chaetodon butterflyfishes, comparing butterflyfish populations from exposed front-reef locations and sheltered back-reef locations. It was expected that the physiological condition, if not the abundance or feeding rates, of coral feeding butterflyfishes would be higher in front-reef locations where coral cover was highest. A difference in the condition, feeding rates or abundance could then be attributable to either an increased quantity of corals or an increase in quality of corals.

\section{MATERIALS AND METHODS}

Sampling locations and study species. This study was conducted between January and April 2000 at Lizard Island $\left(14^{\circ} 40^{\prime} \mathrm{S}, 145^{\circ} 27^{\prime} \mathrm{E}\right)$ on the northern Great Barrier Reef, Australia (Fig. 1). Sampling was conducted at 4 different locations, representative of 2 contrasting reef habitats; South Island and Coconut Beach represent front-reef habitats directly exposed to the prevailing South East trade winds, whereas Osprey Islet and Corner Beach represent back-reef and relatively sheltered habitats. Front-reef locations comprise

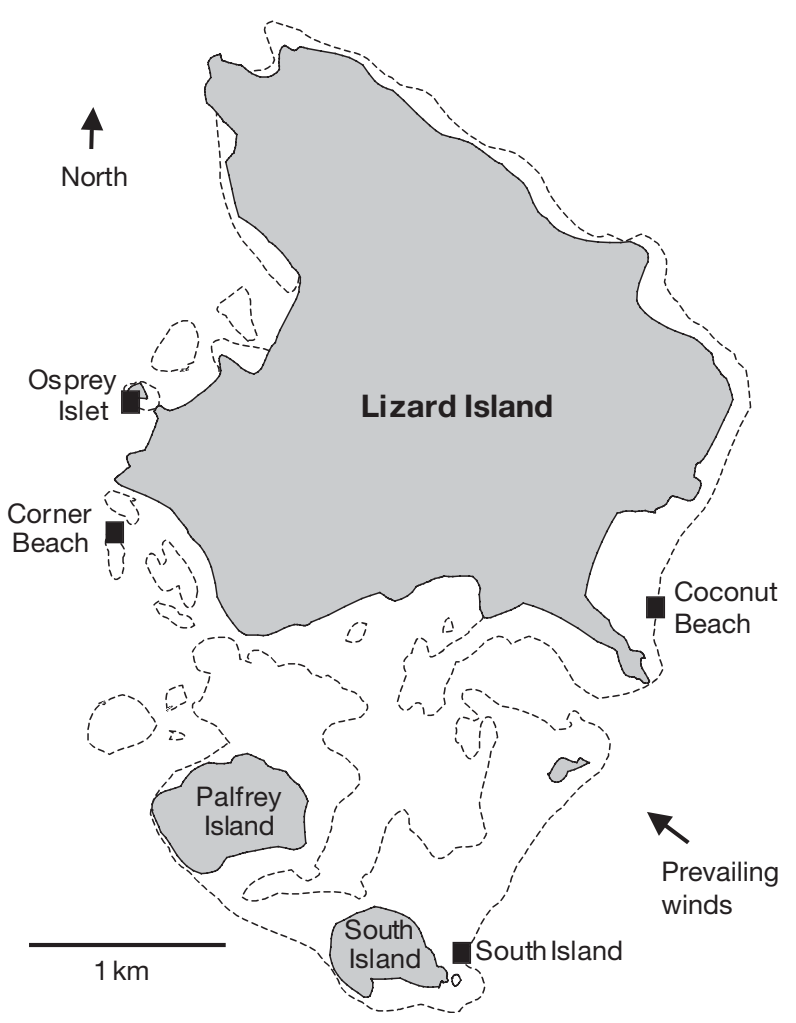

Fig. 1. Chaetodon species. Locations used for the study of abundance patterns and physiological condition at Lizard Island, Great Barrier Reef. South Island and Coconut Beach represent front-reef habitats directly exposed to the prevailing southeast trade winds, whereas Corner Beach and Osprey Islet represent back-reef and relatively sheltered habitats. ---- indicate the approximate reef outline 
contiguous fringing reef with distinct zonation of the reef flat, crest, slope and base. At front-reef locations, sampling was conducted along the shallow reef crest (2 to $5 \mathrm{~m}$ depth). In back-reef locations, the reef was comprised of large patch reefs (200 to $300 \mathrm{~m}$ in diameter), separated by wide expanses of open sand. Here, sampling was conducted on the tops of patch reefs (3 to $6 \mathrm{~m}$ depth).

This study considered 2 of the most common and widespread butterflyfish species, Chaetodon baronessa and C. lunulatus, both of which feed almost exclusively on scleractinian corals (Allen et al. 1998). To compare the abundance of Chaetodon spp. butterflyfishes among locations, we used $50 \times 4 \mathrm{~m}$ visual belt transects. Ten replicate transects were orientated parallel to the reef crest and were run from haphazardlyselected starting points within each location. We recorded the abundance of all Chaetodon butterflyfishes (19 spp. in total) on every transect. Spatial variation in the abundance of $C$. baronessa and C. lunulatus was analysed using analysis of variance (ANOVA). Raw data was log-transformed to meet the ANOVA assumption of homogeneity of variances. All statistical procedures were conducted using SPSS 11.0.

Feeding behaviour of butterflyfishes. The range of prey types consumed by Chaetodon baronessa and C. lunulatus, as well as their relative use of different prey types, was ascertained from field observations of the foraging habits of replicate individuals (after Reese 1975). During feeding observations, individual butterflyfish were followed for $3 \mathrm{~min}$, recording the total number of bites taken from each different coral species (see Table 1). Feeding observations were conducted throughout the day, from 06:00 to 18:00 h. However, in order to account for variation that might be attributable to diurnal feeding patterns, approximately equal numbers of observations were conducted in the morning (06:00 to $10: 00 \mathrm{~h})$, at mid-day (10:00 to $14: 00 \mathrm{~h})$ and in the afternoon (14:00 to 18:00 h) at every location. In all, 50 replicate feeding observations were conducted for each butterflyfish species (C. baronessa and C. lunulatus) at every location (South Island, Coconut Beach, Osprey Islet and Corner Beach). Most individuals continued to feed despite the presence of divers, but observations were aborted if fish fled from the diver or sought shelter within the reef matrix.

Variation in the dietary composition of butterflyfishes may result from differences in the availability of alternate prey and/or specific differences in feeding preferences. To test whether butterflyfishes exhibited significant feeding selectivity, we used the log-likelihood statistic $\left(\chi_{L 2}^{2}\right)$, calculated using the formula:

$$
\sum_{L 2}^{2}=2 \sum_{j=1}^{n} \sum_{i=1}^{I} u_{i j} \ln \left[u_{i j} / \mathrm{E}\left(u_{i j}\right)\right]
$$

where $u_{i j}$ is the proportional use of each prey type (i) by each individual $(j)$ and $\mathrm{E}\left(u_{i j}\right)$ is the expected number of bites taken from prey type $i$ by the $j$ th individual if use is proportional to availability (Manly et al. 1993). The resulting value of $\chi^{2}{ }_{L 2}$ was compared to the chi-squared distribution with $\mathrm{n}(I-1)$ degrees of freedom (where $I$ is the total number of prey categories) to determine the significance of selectivity exhibited by each butterflyfish species (Chaetodon baronessa and C. lunulatus) at each location (South Island, Coconut Beach, Osprey Islet and Corner Beach). Where log-likelihood statistics revealed that butterflyfishes were feeding selectively, we used resource selection functions (Manly et al. 1993) to determine which prey categories were used more or less frequently than expected.

Resource selection functions $\left(w_{i}\right)$ were calculated for all coral species (i) used by each species of butterflyfish, using the formula:

$$
w_{i}=u_{i} / p_{i}
$$

which compares the proportional use $\left(u_{i}\right)$ of each prey category (i) with the proportional availability of that prey category $\left(p_{i}\right)$ within the local area (Manly et al. 1993). We also calculated Bonferroni-corrected 95\% confidence intervals around each selection function, whereby the use of a particular resource was only deemed to be disproportionate to its availability if the $95 \%$ confidence interval did not encompass 1. Selection functions significantly greater than 1 indicated that corals were consumed more than expected from their availability (i.e. selected), while selection functions significantly less than 1 indicated that corals were consumed significantly less than expected (i.e. avoided).

To assess variation in the availability of coral prey, we measured the abundance of corals and composition of coral communities at each location (South Island, Coconut Beach, Osprey Islet and Corner Beach). Coral cover and composition were quantified using 10 replicate $10 \mathrm{~m}$ line intercept transects at each location. Every colony underlying each transect was identified to species and the intercept length for each coral species was measured to the nearest centimetre. Variation in total coral abundance among locations was analysed using ANOVA, while variation in the relative abundance of major prey corals (10 taxa) was analysed using multivariate analyses of variance (MANOVA). Univariate homogeneity was tested using Cochran's test and residual plots were examined to confirm MANOVA assumptions of multivariate homogeneity and normality. Pillai's trace statistic was used to determinethe significance of MANOVA results, following Olsen (1976). Where there were significant differences in the relative abundance of major prey corals, we used canonical discriminant analysis (CDA) to show the relative similarity of coral communities among locations. 
Physiological condition of butterflyfishes. To test for spatial variation in the physiological condition of Chaetodon baronessa and C. lunulatus, we collected 20 individuals of both species at every location (South Island, Coconut Beach, Corner Beach and Osprey Islet). All fish were speared between 10:00 and 14:00 h and kept on ice for 1 to $3 \mathrm{~h}$ before processing. The physiological condition of individual butterflyfishes was assessed using estimates of hepatocyte vacuolation (the proportion of hepatic tissues occupied by intra-cellular vacuoles), which is an indirect measure of total liver lipid stores (Pratchett et al. 2004). Lipid (rather than carbohydrate) is the favoured energy reserve of fishes and the liver is the first site of lipid deposition; therefore, liver lipid content provides a very sensitive measure of the physiological condition and subsequent fitness of individual fish (Green \& McCormick 1999, Pratchett et al. 2004).

To measure hepatocyte vacuolation in Chaetodon baronessa and C. lunulatus, the entire liver from each fish was removed and placed into $10 \%$ calciumbuffered formalin (FAACC) for $4 \mathrm{~d}$. After fixing, hepatic tissues were dehydrated in a graded ethanol series and embedded in paraffin wax. Wax blocks of hepatic tissues were sectioned at $5 \mu \mathrm{m}$, and stained using Mayer's haematoxylin and eosin to emphasise hepatocyte vacuoles. The proportion of vacuoles in hepatic tissues was then quantified using a Weibel

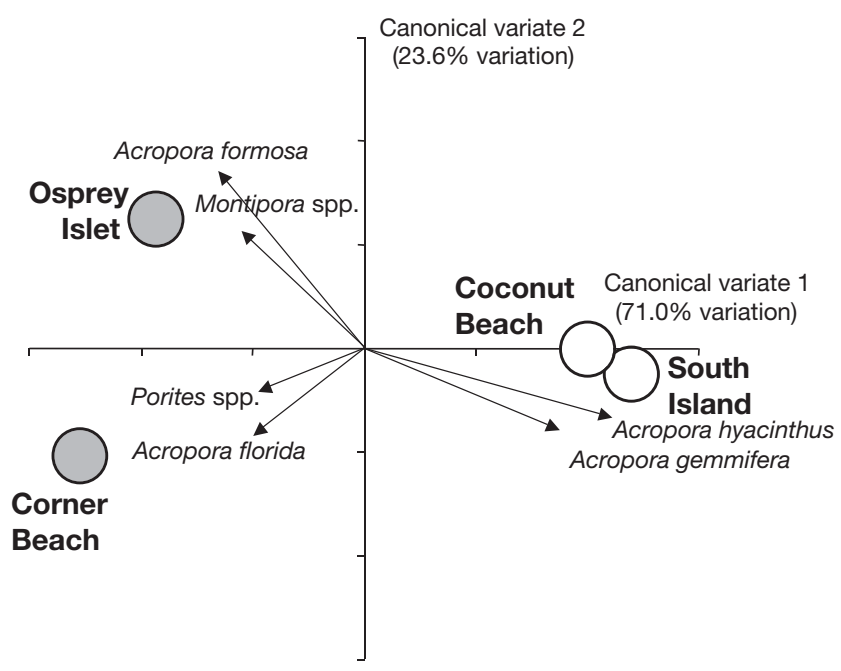

Fig. 2. Scleractinian corals. Comparison of community structure among locations (South Island, Coconut Beach, Osprey Islet, Corner Beach). Results show a canonical discriminant analysis comparing mean coral assemblages. Circles plotted represent $95 \%$ confidence limits around centroids for each location. O: front-reef locations; $\bigcirc$ : back-reef locations. Vectors are structural coefficients of response variables, indicating the relative abundance of main coral species among the 4 locations eyepiece, recording the proportion of points (out of 121) that intersected hepatocyte vacuoles viewed at 400x magnification (following Pratchett et al. 2001). Three replicate counts of hepatocyte vacuoles were recorded for 3 different sections through the different parts of the liver of each fish, giving a total of 9 counts for each fish. Hepatocyte vacuolation was then compared between species (C. baronessa and C. lunulatus) and among locations (South Island, Coconut Beach, Corner Beach and Osprey Islet) using ANOVA.

\section{RESULTS}

\section{Coral cover and composition}

The abundance and composition of scleractinian corals varied greatly among the 4 locations considered during this study. Most notably, coral cover at frontreef locations (South Island and Coconut Beach) was more than double that of back-reef locations (Osprey Islet and Corner Beach). Coral cover was highest at South Island, where scleractinian corals occupied $45.7 \%$ ( $\pm 3.3 \mathrm{SE})$ of hard substrata, followed closely by Coconut Beach, where scleractinian coral cover was $40.6 \%( \pm 4.1 \mathrm{SE})$. In contrast, scleractinian corals occupied less than $20 \%$ of hard substrata at both Osprey Islet $(19.5 \% \pm 3.3 \mathrm{SE})$ and Corner Beach $(17.8 \% \pm$ 2.8 SE). Variation in coral cover among locations was highly significant (ANOVA, $F=17.5, \mathrm{df}=3,39, \mathrm{p}<$ 0.01 ), as were differences in coral composition (MANOVA, Pillai's trace $=47.2, \mathrm{df}=14, \mathrm{p}<0.001$ ). Variation in the composition of coral communities was very apparent between front-reef locations and backreef locations (Fig. 2). However, there were also large differences in the coral communities between the 2 back-reef locations. Many of the corals surveyed (32/56 species) were found at all 4 locations, but the abundance of these taxa varied greatly among locations. Coral communities at the front-reef locations were dominated by Acropora hyacinthus, which accounted for 45.2 and $35.3 \%$ of coral cover at South Island and Coconut Beach, respectively. In contrast, $A$. hyacinthus was virtually absent at back-reef locations. At Osprey Islet, the coral community was dominated by A. formosa and Montipora spp., whereas at Corner Beach, the dominant corals were A. florida and Porites spp. The 1 coral species that was reasonably abundant at all 4 locations was Pocillopora damicornis.

\section{Abundance of butterflyfishes}

Despite significant differences in the abundance and composition of prey corals, mean densities of Chae- 
todon baronessa and C. lunulatus varied very little among the 4 locations. Overall, the mean density of $C$. baronessa was $1.14 \pm 0.67 \mathrm{SE}$ ind. $200 \mathrm{~m}^{-2}$, and though they were slightly more abundant at front-reef locations (South Island and Coconut Beach) compared to back-reef locations (Osprey Islet and Corner Beach), spatial variation in their abundance was not significant (ANOVA, $F=0.36$, df $=3,76, p=0.09$ ). C. lunulatus was twice as abundant as $C$. baronessa at all locations, with a mean density of $2.42 \pm 0.67 \mathrm{SE}$ ind. $200 \mathrm{~m}^{-2}$ across all locations. As for C. baronessa, there was no significant variation in the abundance of $C$. lunulatus among locations (ANOVA, $F=0.34, \mathrm{df}=3,76, \mathrm{p}=0.21$ ).

Although there was no spatial variation in the abundance of the 2 study species (Chaetodon baronessa and C. lunulatus), the abundance of congeners varied greatly among the 4 locations. Mean densities of butterflyfishes were very similar for the 2 front-reef locations, South Island $\left(17.2 \pm 2.3 \mathrm{SE}\right.$ fish $\left.200 \mathrm{~m}^{-2}\right)$ and Coconut Beach $\left(18.7 \pm 2.2 \mathrm{SE}\right.$ fish $\left.200 \mathrm{~m}^{-2}\right)$. However, densities of butterflyfishes at the front-reef locations were more than double those at the back-reef locations; Osprey Islet $\left(8.0 \pm 0.9 \mathrm{SE}\right.$ fish $\left.200 \mathrm{~m}^{-2}\right)$ and Corner Beach $\left(8.5 \pm 1.4 \mathrm{SE}\right.$ fish $\left.200 \mathrm{~m}^{-2}\right)$. Spatial variation in the total densities of butterflyfishes resulted primarily from differences in the abundance of $C$. citrinellus, which was 5 to 6 times more abundant at exposed locations than at back-reef locations. Moreover, there were 3 species (C. kleinii, C. rafflesii and C. trifascialis) that were found only at front-reef locations, whereas all other species (C. aureofasciatus, C. auriga, C. citrinellus, C. ephippium, C. lineolatus, C. lunula, C. melannotus, C. pelewensis, C. plebius, C. rainfordi, C. speculum, C. ulietensis, C. unimaculatus and C. vagabundus) were recorded at all locations.

\section{Feeding behaviour of butterflyfishes}

Chaetodon baronessa and C. lunulatus fed exclusively on scleractinian corals and consumed a wide variety of different coral species, including at least 56 species from 11 different families (Table 1). However, both butterflyfish species exhibited significant selectivity in their patterns of feeding, using some coral species disproportionately more or less than predicted by their availability (Table 2). C. baronessa exhibited particularly strong selectivity (especially at front-reef locations) and tended to feed predominantly on just 1 or 2 different coral species at each location (Fig. 3). At South Island, C. baronessa consumed 18 different coral species (Table 1), but $87.6 \%$ of all bites were taken from Acropora hyacinthus. At Coconut Beach, C. baronessa consumed 24 different coral species; nevertheless, $75.7 \%$ of bites were still taken from A. hyacinthus
(Fig. 3). The predominance of A. hyacinthus in the diet of C. baronessa at South Island and Coconut Beach is not surprising given that $A$. hyacinthus was the dominant coral at both these front-reef locations. However, C. baronessa consumed A. hyacinthus in far greater proportions than would be expected from its availability (Table 2).

Compared to front-reef locations, at back-reef locations (where Acropora hyacinthus was scarce), Chaetodon baronessa consumed a wider range of different coral species (Table 1) and was less selective in its choice of prey (Table 2). Even so, C. baronessa tended to feed predominantly on just 1 or 2 different coral species. At Osprey Islet, C. baronessa consumed 32 different coral species, but $44 \%$ of bites were taken from Pocillopora damicornis (Fig. 3). In the absence of A. hyacinthus, C. baronessa selectively consumed P. damicornis over most other coral species (Table 2). At Corner Beach, C. baronessa consumed both P. damicornis and A. florida in approximately equal proportions (Fig. 3). Both these coral species were consumed in greater proportions than expected from their availability, as were Galaxea spp. (Table 2).

The dietary composition of Chaetodon lunulatus also differed among locations, but $C$. lunulatus used many different coral species (between 29 and 33 species) at every location (Table 1) and was less selective than C. baronessa (Table 2). At South Island, C. lunulatus consumed mainly Acropora hyacinthus, taking $38 \%$ of all bites from this 1 coral species (Fig. 4). However, electivity indices revealed that $C$. lunulatus was not feeding on $A$. hyacinthus in greater proportions than it was available (Table 2). At Coconut Beach, C. lunulatus consumed $A$. hyacinthus in lower proportions than expected from its relative abundance (Table 2), taking less than $15 \%$ of bites from this abundant coral species. The only coral taxa that $C$. lunulatus consumed more than expected at all locations (i.e. seemingly selected at all locations) were massive Porites spp. (Table 2). At back-reef locations (Osprey Islet and Coconut Beach), C. lunulatus consumed several different coral species (A. intermedia, Pocillopora damicornis and Porites spp.) in approximately equal proportions. There were, however, slight differences in dietary composition between Osprey Islet and Coconut Beach, which were associated with variation in the availability of different coral species. Most notably, Montipora was particularly abundant at Osprey Islet (Fig. 2) and was the main coral eaten by C. lunulatus at this location (Fig. 4).

Despite differences in dietary composition, the mean rate of feeding for both Chaetodon baronessa and C. lunulatus was remarkably constant among locations. Bite rates were highly variable among individuals. For example, the bite rates of C. baronessa 
Table 1. Chaetodon baronessa and C. lunulatus. Range of prey categories used by the 2 butterflyfish species at each location (South Island, Coconut Beach, Osprey Islet and Corner Beach). Prey categories used by each butterflyfish at each location are indicated by +

\begin{tabular}{|c|c|c|c|c|c|c|c|c|}
\hline \multirow[b]{2}{*}{ Prey category } & \multicolumn{4}{|c|}{ Chaetodon baronessa } & \multicolumn{4}{|c|}{ Chaetodon lunulatus } \\
\hline & $\begin{array}{l}\text { South } \\
\text { Island }\end{array}$ & $\begin{array}{c}\text { Coconut } \\
\text { Beach }\end{array}$ & $\begin{array}{c}\text { Osprey } \\
\text { Islet }\end{array}$ & $\begin{array}{l}\text { Corner } \\
\text { Beach }\end{array}$ & $\begin{array}{l}\text { South } \\
\text { Island }\end{array}$ & $\begin{array}{c}\text { Coconut } \\
\text { Beach }\end{array}$ & $\begin{array}{l}\text { Osprey } \\
\text { Islet }\end{array}$ & $\begin{array}{l}\text { Corner } \\
\text { Beach }\end{array}$ \\
\hline \multicolumn{9}{|l|}{ ACROPORIDAE } \\
\hline Acropora cytherea & + & & & & + & & & \\
\hline A. digitifera & + & & & & + & + & & \\
\hline A. donei & & & & + & & + & & \\
\hline A. florida & + & + & + & + & + & + & + & + \\
\hline A. formosa & + & + & + & & + & + & + & \\
\hline A. gemmifera & + & + & + & & + & + & + & + \\
\hline A. grandis & & & + & + & & + & + & \\
\hline A. humilis & + & + & + & + & + & + & & + \\
\hline A. hyacinthus & + & + & & & + & + & & \\
\hline A. intermedia & & & + & + & + & + & + & + \\
\hline A. loripes & & & & + & & & + & + \\
\hline A. millepora & + & + & + & & + & + & + & + \\
\hline A. monticulosa & & & & & + & + & & \\
\hline A. nasuta & & + & + & + & + & + & + & + \\
\hline A. robusta & + & + & + & & + & + & & \\
\hline A. sarmentosa & & & + & + & & & + & + \\
\hline A. secale & & + & & + & + & + & + & \\
\hline A. selago & & & + & & + & + & & + \\
\hline A. valida & + & + & + & + & + & + & & \\
\hline Astreopora spp. & & & + & & + & & + & \\
\hline Isopora spp. & + & + & + & + & + & + & + & + \\
\hline Montipora spp. & & + & + & + & + & + & + & + \\
\hline \multicolumn{9}{|l|}{ POCILLOPORIDAE } \\
\hline Pocillopora damicornis & + & + & + & + & + & + & + & + \\
\hline P. eydouxi & + & + & & & + & + & & \\
\hline P. verrucosa & + & + & + & + & + & + & + & \\
\hline Seriatopora hystrix & & & + & + & + & & + & + \\
\hline Stylophora pistillata & + & + & + & + & + & + & + & + \\
\hline \multicolumn{9}{|l|}{ FAVIIDAE } \\
\hline Cyphastrea seriala & & & & & + & & + & \\
\hline Diploastrea heliopora & & + & & + & & & & \\
\hline Favia favus & & & + & & & + & & + \\
\hline F. pallida & & + & & + & & & & + \\
\hline F. speciosa & & & & & & + & + & \\
\hline F. stelligera & & & & & + & & & \\
\hline Favites abdita & + & + & + & & + & + & & + \\
\hline F. halicora & & & & & + & + & + & \\
\hline Goniastrea retiformes & & + & + & + & + & + & + & + \\
\hline Leptastrea transversa & & & + & & & & + & \\
\hline Leptoria phrygia & + & & + & & & + & & + \\
\hline Montastrea spp. & & & & + & & & & + \\
\hline Platygyra daedalea & & & & + & & & + & + \\
\hline$P$. sinensis & & & + & & & & & \\
\hline P. verweyi & & & & & & & + & \\
\hline \multicolumn{9}{|l|}{ MUSSIDAE } \\
\hline Lobophyllia spp. & & & + & + & & & & + \\
\hline Symphyllia recta & & + & + & + & & + & + & + \\
\hline \multicolumn{9}{|c|}{ Other scleractinian corals } \\
\hline Fungiidae & & + & + & + & & & + & + \\
\hline Coeloseris mayeri & & & + & + & + & + & + & + \\
\hline Pavona varians & & & & & & & + & \\
\hline Psammacora spp. & & & + & & & & + & \\
\hline Galaxea spp. & & + & + & + & + & + & + & + \\
\hline Hydnophora spp. & & & & & + & + & & + \\
\hline Porites spp. & + & + & + & + & + & + & + & + \\
\hline Turbinaria spp. & & & & & & & & + \\
\hline No. categories used & 18 & 24 & 32 & 27 & 32 & 33 & 31 & 29 \\
\hline
\end{tabular}


Table 2. Chaetodon baronessa and C. lunulatus. Patterns of feeding selectivity. Both species of butterflyfish exhibited significant feeding selectivity $\left(\chi^{2}{ }_{L 2}\right)$ at all locations $(\mathrm{p}<0.01)$. +: corals used significantly more than expected; -: corals used significantly less than expected; 0 : corals that were used in approximate accordance with their availability; NU: not used; NA: not available

\begin{tabular}{|c|c|c|c|c|c|c|c|c|c|c|c|}
\hline & \multicolumn{11}{|c|}{ Prey category } \\
\hline & $\chi_{L 2}^{2}$ & $\begin{array}{c}\text { Acropora } \\
\text { florida }\end{array}$ & $\begin{array}{c}A . \\
\text { formosa }\end{array}$ & $\begin{array}{c}\text { A. } \\
\text { gemmi- } \\
\text { fera }\end{array}$ & $\begin{array}{c}\text { A. } \\
\text { hyacin- } \\
\text { thus }\end{array}$ & $\begin{array}{l}\text { A. } \\
\text { inter- } \\
\text { media }\end{array}$ & $\begin{array}{c}\text { Pocillopora } \\
\text { dami- } \\
\text { cornis }\end{array}$ & $\begin{array}{l}\text { Isopora } \\
\text { spp. }\end{array}$ & $\begin{array}{l}\text { Montipora } \\
\text { spp. }\end{array}$ & $\begin{array}{c}\text { Galaxea } \\
\text { spp. }\end{array}$ & $\begin{array}{c}\text { Porites } \\
\text { spp. }\end{array}$ \\
\hline \multicolumn{12}{|l|}{ C. baronessa } \\
\hline South Island & $6.9 \times 10^{3}$ & 0 & 0 & - & + & NU & 0 & 0 & NU & NA & NU \\
\hline Coconut Beach & $6.3 \times 10^{3}$ & 0 & - & 0 & + & NU & 0 & 0 & - & 0 & 0 \\
\hline Osprey Islet & $4.5 \times 10^{3}$ & 0 & 0 & 0 & NU & 0 & + & 0 & - & 0 & - \\
\hline Corner Beach & $3.5 \times 10^{3}$ & + & NA & - & NA & 0 & + & 0 & - & + & - \\
\hline \multicolumn{12}{|l|}{ C. lunulatus } \\
\hline South Island & $3.2 \times 10^{3}$ & 0 & 0 & 0 & 0 & 0 & 0 & + & 0 & NA & + \\
\hline Coconut Beach & $2.9 \times 10^{3}$ & - & NU & + & - & 0 & + & + & - & 0 & + \\
\hline Osprey Islet & $1.9 \times 10^{3}$ & 0 & 0 & 0 & NU & + & 0 & 0 & - & 0 & + \\
\hline Corner Beach & $2.5 \times 10^{3}$ & 0 & NA & 0 & NA & + & 0 & 0 & 0 & 0 & + \\
\hline
\end{tabular}

ranged from 81 bites to a low of just 11 bites during the 3 min observation periods. The mean bite rates of $C$. baronessa were slightly higher at South Island (41.29 \pm 2.1 $\mathrm{SE}$ bites $\left.3 \mathrm{~min}^{-1}\right)$ and at Osprey Islet (40.47 $\pm 2.0 \mathrm{SE}$ bites $3 \mathrm{~min}^{-1}$ ) compared to Coconut Beach (34.42 \pm 1.9
SE bites $\left.3 \mathrm{~min}^{-1}\right)$ and Corner Beach $(34.72 \pm 1.9 \mathrm{SE}$ bites $3 \mathrm{~min}^{-1}$ ). However, there was no significant difference in mean bite rates for $C$. baronessa among locations (ANOVA, $F=2.20, \mathrm{df}=3,196, \mathrm{p}=0.08$ ), nor was there any significant difference among times of

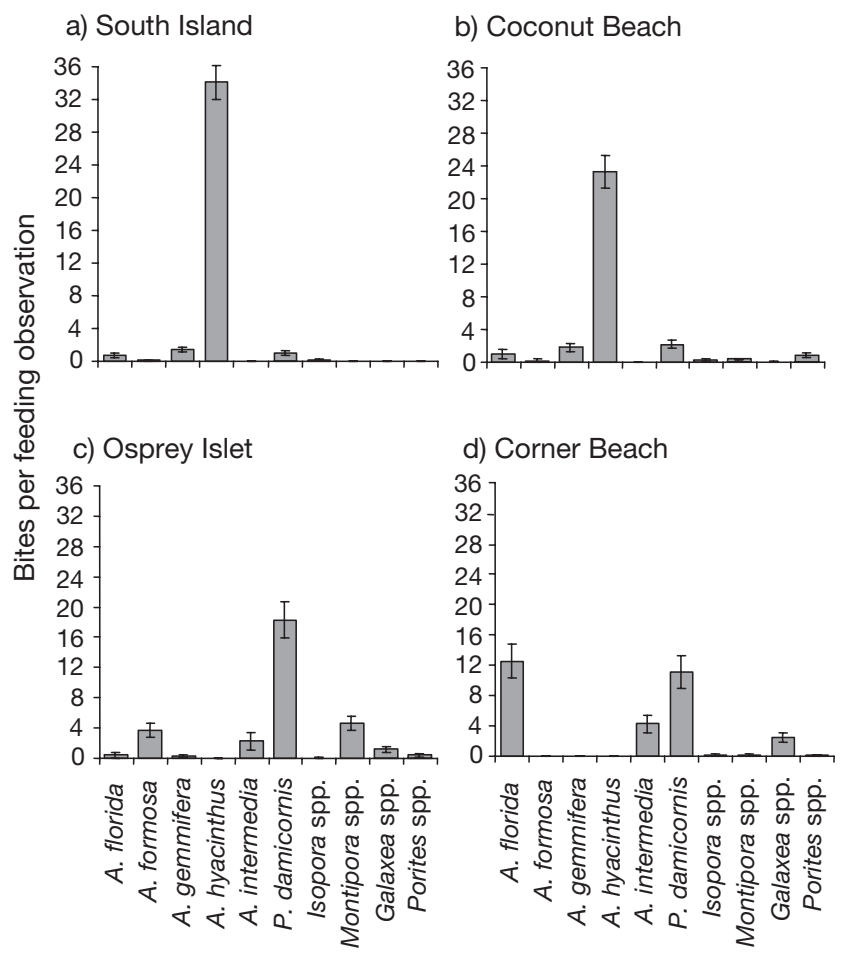

Fig. 3. Chaetodon baronessa. Comparison of dietary composition among 4 locations: $(\mathrm{a}, \mathrm{b})$ front-reef, $(\mathrm{c}, \mathrm{d})$ back-reef. Data presented are the mean number of bites $( \pm \mathrm{SE})$ per 3 min observation on each of 10 dominant coral species, including 5 Acropora species and 1 Pocillopora species ( $\mathrm{n}=50$ observations per location)

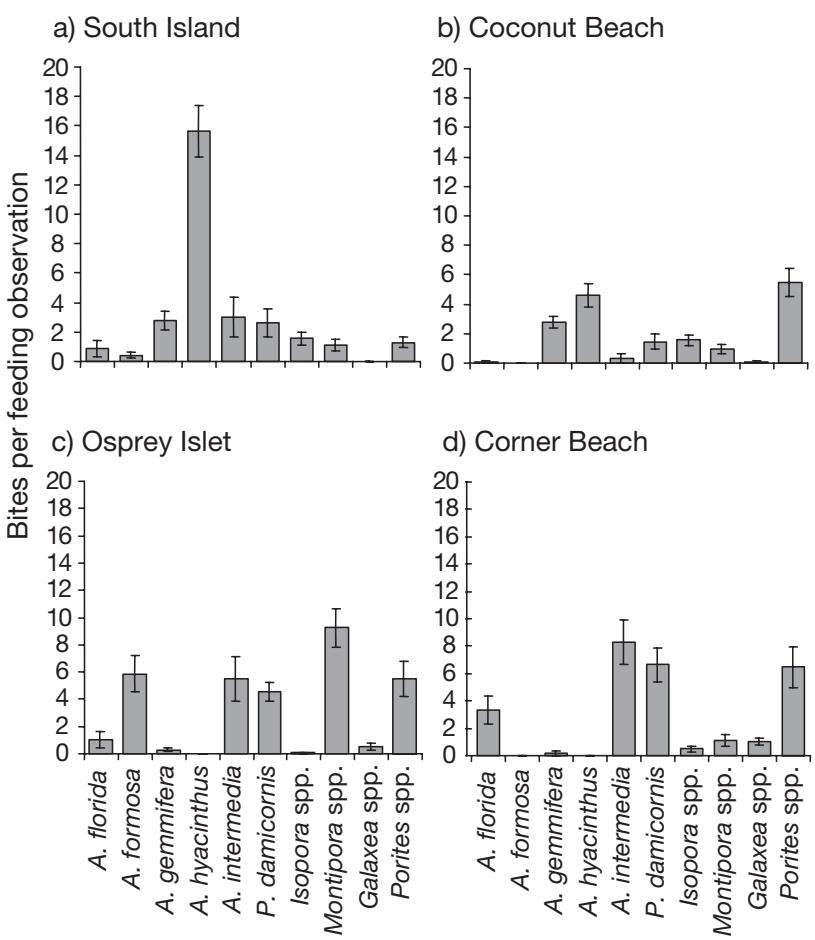

Fig. 4. Chaetodon lunulatus. Comparison of dietary composition among 4 locations: $(\mathrm{a}, \mathrm{b})$ front-reef, $(\mathrm{c}, \mathrm{d})$ back-reef. Data presented are the mean number of bites $( \pm \mathrm{SE})$ per 3 min observation on each of 10 dominant coral species, including 5 Acropora species and 1 Pocillopora species ( $\mathrm{n}=50$ observations per location) 


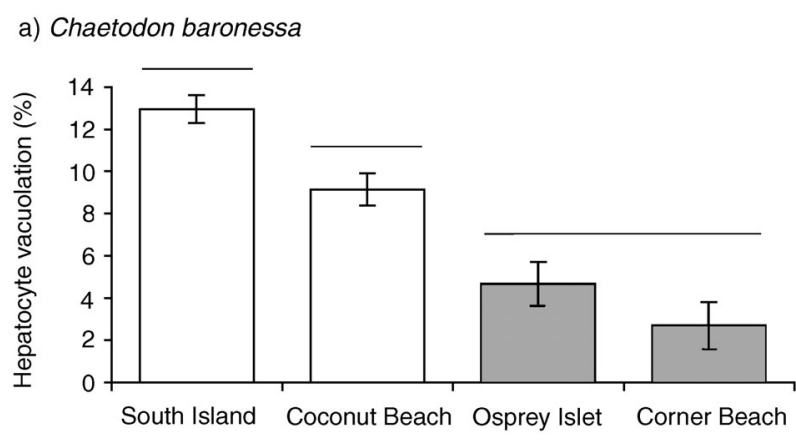

b) Chaetodon Iunulatus

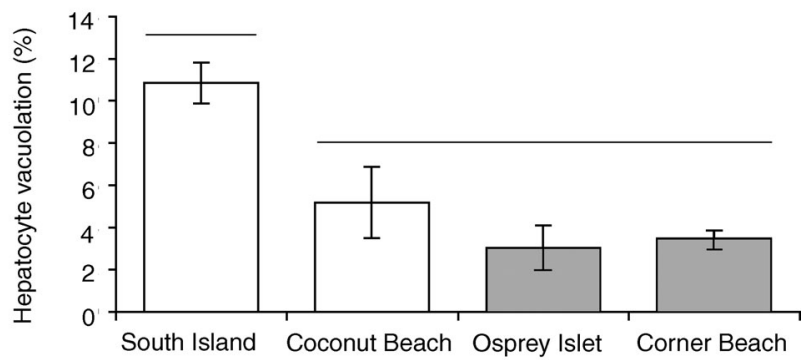

Fig. 5. Chaetodon baronessa and C. lunulatus. Comparison of hepatocyte vacuolation for (a) Chaetodon baronessa and (b) C. lunulatus among 4 different locations. Data presented are the mean proportion of hepatocyte vacuoles in cross-sections through the liver of 20 replicate fish $( \pm \mathrm{SE})$. White bars indicate front-reef locations and grey bars indicate back-reef locations. Horizontal lines represent homogeneous subsets identified by Tukey's HSD post-hoc test

day (ANOVA, $F=0.97$, $d f=2,196, p=0.42$ ). A comparison between butterflyfish species revealed that C. baronessa tended to feed at a higher rate (34.12 \pm 1.1 SE bites $\left.3 \mathrm{~min}^{-1}\right)$ than C. lunulatus $(28.73 \pm 1.2 \mathrm{SE}$ bites $3 \mathrm{~min}^{-1}$ ) and feeding rates of $C$. lunulatus were also more variable. Bite rates for $C$. lunulatus ranged from 97 bites to just 1 bite during the 3 min observation periods. Bite rates of $C$. lunulatus did not differ with time of day (ANOVA, $F=0.94$, df =2,196, $p=0.43$ ), but did differ among locations (ANOVA, $F=6.83, \mathrm{df}=$ $3,196, \mathrm{p}<0.01)$. Notably, mean bite rates for $C$. lunulatus were much lower at Coconut Beach $(22.86 \pm 1.7 \mathrm{SE}$ bites $\left.3 \mathrm{~min}^{-1}\right)$ than at South Island $(40.88 \pm 2.7 \mathrm{SE}$ bites $\left.3 \mathrm{~min}^{-1}\right)$, Osprey Islet $\left(38.86 \pm 2.6 \mathrm{SE}\right.$ bites $\left.3 \mathrm{~min}^{-1}\right)$ and Corner Beach $\left(31.46 \pm 2.0 \mathrm{SE}\right.$ bites $\left.3 \mathrm{~min}^{-1}\right)$.

\section{Physiological condition}

In accordance with differences in dietary composition, physiological condition, as measured by hepatocyte vacuolation, differed significantly among locations for both Chaetodon baronessa (ANOVA, $F=$
13.34, $\mathrm{df}=3,76, \mathrm{p}<0.01$ ) and $C$. lunulatus (ANOVA, $F=3.72$, df $=3,76, \mathrm{p}<0.05)$. For $C$. baronessa, the mean proportion of hepatocyte vacuoles in cross-sections through the liver ranged from $12.94 \%( \pm 0.67 \mathrm{SE})$ for individuals collected from South Island to $2.67 \%$ $( \pm 1.12 \mathrm{SE})$ for individuals from Corner Beach. Overall, hepatocyte vacuolation was much higher for individuals collected from front-reef locations (South Island and Coconut Beach) compared to back-reef locations (Fig. 5). However, there was also a difference between the 2 front-reef locations, with $C$. baronessa collected from South Island having a greater proportion of hepatocyte vacuoles than individuals from Coconut Beach (Fig. 5). There was no consistent pattern of variation in hepatocyte vacuolation between front-reef and backreef habitats for C. lunulatus (Fig. 5). Rather, at South Island, C. lunulatus had much higher levels of hepatocyte vacuolations compared to individuals collected from all other locations (Fig. 5).

\section{DISCUSSION}

The size of reef fish populations often varies in accordance with spatial variation in coral abundance and composition (e.g. Bell \& Gazlin 1984, Bouchon-Navaro et al. 1985, Munday et al. 1997, Holbrook et al. 2000), particularly for coral-feeding butterflyfishes (e.g. Sano et al. 1984, 1987, Bouchon-Navaro et al. 1985, Williams 1986, Lewis 1997, Cadoret et al. 1999). However, at Lizard Island, densities of neither Chaetodon baronessa nor C. lunulatus varied between front-reef and back-reef locations, despite a 2-fold difference in the abundance of scleractinian coral, as well as significant variation in the composition of coral communities (see also Bell et al. 1985, Roberts \& Ormond 1987). The strength of relationships between butterflyfish abundance and scleractinian coral cover vary greatly among different studies. These differences may relate to differences in sampling and scale between studies (Bell et al. 1985, Syms 1995), or from real differences in the recruitment history and demographic parameters of individual species (Jones 1990, 1991). In addition, different processes (e.g. recruitment versus resource availability) may regulate the size of reef fish populations in different locations or at different times (Bell et al. 1985). Where fish populations are regulated by recruitment (e.g. Wellington \& Victor 1985, Doherty \& Fowler 1994), their abundance could vary independently of differences in prey availability, competition or predation.

Although there was no difference in the abundance of butterflyfishes Chaetodon baronessa and C. lunulatus between contrasting reef habitats, there were significant differences in their physiological condition. 
Similarly, Pratchett et al. (2004) documented significant declines in the condition of $C$. lunulatus during extensive coral-depletion caused by bleaching in the central Great Barrier Reef. This study, conducted over 2 yr (2000 to 2002), showed that there was no change in the abundance of $C$. lunulatus, but hepatocyte vacuolation was $50 \%$ lower in fish collected after the bleaching event compared to fish collected before the bleaching (Pratchett et al. 2004). These data, together with the findings of the present study, suggest that variation in the abundance and/or composition of scleractinian corals can have significant effects on the physiological condition (specifically liver lipid storage) of coralfeeding butterflyfishes.

Physiological condition is a major determinant of individual fitness in fishes, affecting growth, survivorship and reproductive success (Jones \& McCormick 2002). Therefore, variation in coral abundance and composition could have a significant influence on the structure and dynamics of butterflyfish populations, and could even have long-term effects on population abundance. The amount of food available to gravid females has been shown to be directly related to individual fecundity (Wooten 1990) and also affects the viability of offspring (McCormick 2003). The quality and quantity of prey resources are also fundamental to the growth of fishes (e.g. Clifton 1995). Limited availability of prey rarely causes mortality directly, but fishes living in habitats with limited prey may have much lower survivorship, which could result in lagged effects on population size (Jones \& McCormick 2002).

Variation in the physiological condition of Chaetodon baronessa and C. lunulatus (among locations) appeared to be related to differences in the composition of coral communities, more than to differences in mean coral abundance. Feeding rates of $C$. baronessa and $C$. lunulatus varied very little among the 4 locations, suggesting that there must have been sufficient coral at every location to meet basic dietary requirements (sensu Tricas 1989). However, differences in dietary composition are likely to have had major effects on the energetic intake of butterflyfishes in different locations (Birkeland \& Neudecker 1981, Tricas 1989). Both C. baronessa and C. lunulatus were 'generalist' coral feeders, foraging on a wide variety of different coral species (cf. C. trifascialis, Irons 1989) but preferentially consumed a few different species, which may represent coral species of highest nutritional quality (Tricas 1989). For both C. baronessa and C. lunulatus, physiological condition improved with increased consumption of Acropora hyacinthus. Although the nutritional quality of this coral species has never been tested, these findings suggest that A. hyacinthus may be the most profitable prey species for both C. baronessa and C. lunulatus (see also Irons
1988, 1989). Further, the feeding behaviour of C. baronessa is consistent with expectations for a fish foraging on an optimal prey (sensu Hughes 1980), specialising on A. hyacinthus when it is abundant (in frontreef locations), but becoming more generalist when A. hyacinthus is scarce (in back-reef locations). A. hyacinthus was recorded at Osprey Islet in very low quantities (1 small colony in 10 replicate $10 \mathrm{~m}$ transects) and we did not observe any individuals of either C. baronessa or C. lunulatus feeding on this colony. Where A. hyacinthus was unavailable, both butterflyfish species tended to make use of the most abundant coral species. For example, large stands of A. florida at Corner Beach were heavily exploited by both $C$. baronessa and C. lunulatus.

Variation in dietary composition and patterns of feeding are known to influence physiological condition in fishes (Pulliam 1974, Charnov 1976, Stephens \& Krebs 1986, Bruggemann et al. 1994, Green \& McCormick 1999). However, variation in the condition of butterflyfishes may also be attributable to factors other than prey availability (e.g. disease, predation or competition). Importantly, inter-specific competition can modify access to available resources. Holbrook \& Schmitt (1986) showed that the physiological condition of the black surfperch Embiotoca jacksoni is reduced in the presence of the striped surfperch Embiotoca lateralis, which restrict E. jacksoni access to profitable shallow water feeding grounds. Inter-specific competition is also important for Chaetodon butterflyfishes, affecting fine-scale distributions of individual species and restricting access to certain prey resources (Anderson et al. 1981, Bouchon-Navaro \& Bouchon 1981). At Lizard Island, densities of Chaetodon spp. butterflyfishes and also the intensity of inter-specific competition among Chaetodon species have been shown to be highest at front-reef locations (M. S. Pratchett \& M. L. Berumen unpubl. data). Therefore, if competition did have an important influence on the condition of butterflyfish populations in the 2 different habitat types, it would counter the observed trends in physiological condition, affecting individuals at frontreef locations far more than at back-reef locations.

Inter-specific competition may be important in explaining differences in the diet and condition of butterflyfishes between front-reef locations (South Island and Coconut Beach), where coral cover and composition were very similar. At South Island, both Chaetodon baronessa and C. lunulatus fed mainly on the tabulate coral, Acropora hyacinthus. This concurs with several other studies (Reese 1975, Irons 1989), indicating that A. hyacinthus might be the most preferred coral species for a variety of different Chaetodon species. However, at Coconut Beach, C. lunulatus consumed A. hyacinthus in much lower proportions than expected from 
its relative abundance. C. baronessa also consumed much less A. hyacinthus at Coconut Beach than at South Island. These differences may be related to differences in the abundance of $C$. trifascialis, which might exclude $C$. lunulatus (and to a much lesser extent, C. baronessa) from feeding on A. hyacinthus. C. baronessa and $C$. trifascialis are the dominant butterflyfish competitors at Lizard Island (M. S. Pratchett \& M. L. Berumen unpubl. data), forming well-defended territories in the vicinity of $A$. hyacinthus colonies (see also Reese 1975). Therefore, C. lunulatus would have limited access to colonies of $A$. hyacinthus and may feed very little on this coral even though $A$. hyacinthus may be its preferred prey. Interference competition by $C$. trifascialis may also explain the unusually low feeding rate of C. lunulatus at Coconut Beach. C. trifascialis feeds almost exclusively on $A$. hyacinthus and maintains heavily defended territories around patches of A. hyacinthus (Irons 1988, 1989). Reese (1981) showed that densities of C. trifascialis and C. baronessa are inversely correlated on reefs in Papua New Guinea, which may be evidence of strong inter-specific competition between these species (Bell et al. 1985). At Lizard Island, densities of $C$. trifascialis were much higher at Coconut Beach $\left(1.9 \pm 0.4 \mathrm{SE}\right.$ fish $\left.200 \mathrm{~m}^{-2}\right)$, compared to South Island $\left(0.6 \pm 0.3 \mathrm{SE}\right.$ fish $\left.200 \mathrm{~m}^{-2}\right)$, corresponding with lower consumption of $A$. hyacinthus by both C. lunulatus and C. baronessa. We, therefore, suggest that C. baronessa, C. lunulatus and C. trifascialis all compete for access to A. hyacinthus, and observed feeding preferences may be confounded by competition. Conclusive evidence for the influence of interspecific competition on dietary composition of Chaetodon spp. butterflyfishes requires the removal of dominant competitors $(C$. baronessa and/or C. trifascialis), followed by the assessment of whether there is a subsequent shift in dietary composition of sub-ordinate species (e.g. C. lunulatus).

In conclusion, this study strongly suggests that differences in prey availability can have significant effects on the physiological condition of fishes living in different habitats. These differences in physiological condition may also have ramifications for reproduction, growth and long-term survivorship (sensu Jones \& McCormick 2002). In this study, we show significant variation in the physiological condition of coralfeeding butterflyfishes among habitats with varying coral composition and cover. Diet alone may not be responsible for such variation in the energetics of coral-feeding butterflyfish populations, but whatever the reason, there are clear differences in the condition of butterflyfishes living in these different habitats. Importantly, these differences occurred over very small spatial scales (within reefs), and must be considered when comparing reef fish populations within and between coral reefs. In previous studies (e.g. Eckert 1985, Shulman 1985), population size of reef fish has been used to infer habitat quality. However, this study has shown that dramatic differences in the condition of reef fishes may exist as a consequence of differences in habitat and that these differences are not necessarily reflected in population size.

Acknowledgements. This study was conducted in partial fulfilment of an honours degree from the University of Arkansas, with research conducted at James Cook University. Research was funded by the Roy and Christine Sturgis Charitable Trust and by the Barry Goldwater Scholarship to M.L.B. Field assistance was provided by M. Kospartov, R. Williams, J. Salmond, D. deVere and L. Jordan. Comments by J. H. Choat and 4 anonymous reviewers greatly improved the manuscript. This is contribution number 142 of the Centre for Coral Reef Biodiversity at James Cook University.

\section{LITERATURE CITED}

Allen GR, Steene R, Allen M (1998) A guide to angelfishes and butterflyfishes. Vanguard Press, Perth

Anderson GRV, Ehrlich AH, Ehrlich PR, Roughgarden JD, Russell BC, Talbot FH (1981) The community structure of coral reef fishes. Am Nat 117:476-495

Bell JD, Gazlin R (1984) Influence of live coral cover on coralreef fish communities. Mar Ecol Prog Ser 15:265-274

Bell JD, Harmelin-Vivien M, Galzin R (1985) Large scale spatial variation in abundance in butterflyfishes (Chaetodontidae) on Polynesian reefs. Proc 5th Int Coral Reef Symp 5:421-426

Birkeland C, Neudecker S (1981) Foraging behaviour of two Caribbean chaetodontids: Chaetodon capistratus and $C$. aculeatus. Copeia 1981:169-178

Bouchon-Navaro Y, Bouchon C (1989) Correlations between chaetodontid fishes and coral communities of the Gulf of Aqaba (Red Sea). Environ Biol Fish 25:47-60

Bouchon-Navaro Y, Bouchon C, Harmelin-Vivien ML (1985) Impact of coral degradation on a Chaetodontid fish assemblage (Moorea, French Polynesia). Proc 5th Int Coral Reef Symp 5:427-432

Bruggemann J, Begeman J, Bosma E, Verburg P, Breeman A (1994) Foraging by the stoplight parrotfish Sparisoma viride. II. Intake and assimilation of food, protein, and energy. Mar Ecol Prog Ser 106:57-71

Cadoret L, Aderjoud M, Tsuchiya M (1999) Spatial distribution of chaetodontid fish in coral reefs of the Ryukyu Islands, southern Japan. J Mar Biol Assoc UK 79:725-735

Chabanet P, Ralambondrainy H, Amanieu M, Faure G, Galzin R (1997) Relationships between coral reef substrata and fish. Coral Reefs 16:93-102

Charnov EL (1976) Optimal foraging: The marginal value theorem. Theor Popul Biol 9:129-136

Clifton KE (1995) Asynchronous food availability on neighboring Caribbean coral reefs determines seasonal patterns of growth and reproduction for the herbivorous parrotfish Scarus iserti. Mar Ecol Prog Ser 116:39-46

Doherty PJ, Fowler AJ (1994) An empirical test of recruitment limitation in a coral reef fish on the Great Barrier Reef. Science 263:935-939

Doherty PJ, Williams DM (1988) The replenishment of coral reef fish populations. Oceanogr Mar Biol Annu Rev 26: $487-551$ 
Done TJ (1982) Patterns in the distribution of coral communities across the central Great Barrier Reef. Coral Reefs 1:95-107

Eckert GJ (1985) Settlement of coral reef fishes to different natural substrata and at different depths. Proc 5th Int Coral Reef Symp 5:385-390

Findley JS, Findley MT (1985) A search for pattern in butterflyfish communities. Am Nat 126:800-816

Fowler AJ (1990) Spatial and temporal patterns of distribution and abundances of chaetodontid fishes at One Tree Reef, southern GBR. Mar Ecol Prog Ser 64:39-53

Green BS, McCormick MI (1999) Influence of larval feeding history on the body condition of Amphiprion melanopus. J Fish Biol 55:1273-1289

Hixon MA, Carr MH (1997) Synergistic predation, density dependence, and population regulation in marine fish. Science 277:946-949

Holbrook SJ, Schmitt RJ (1986) Seasonally fluctuating resources and temporal variability of interspecifc competition. Oecologia 69:1-11

Holbrook SJ, Forrester GE, Schmitt RJ (2000) Spatial patterns in abundance of a damselfish reflect availability of suitable habitat. Oecologia 122:109-120

Hughes RN (1980) Optimal foraging theory in the marine context. Oceanogr Mar Biol Annu Rev 18:423-481

Irons D (1988) Behavioral interactions of the butterflyfish Chaetodon trifascialis at Johnston Atoll. Pac Sci 42: 122-123

Irons DK (1989) Temporal and areal feeding behaviour of the butterflyfish Chaetodon trifascialis at Johnston Atoll. Environ Biol Fish 25:187-193

Jones GP (1990) The importance of recruitment to the dynamics of a coral reef fish population. Ecology 71:1691-1698

Jones GP (1991) Postrecruitment processes in the ecology of coral reef fish populations: a multifactorial prespective. In: Sale PF (ed) The ecology of fishes on coral reefs. Academic Press, San Diego, CA, p 294-237

Jones GP, McCormick MI (2002) Numerical and energetic processes in the ecology of coral reef fishes. In: Sale PF (ed) Coral reef fishes: dynamics and diversity in a complex ecosystem. Academic Press, San Diego, CA, p 221-238

Levin PS (1998) The significance of variable and densityindependent post-recruitment mortality in local populations of reef fishes. Aust J Ecol 23:246-251

Lewis AR (1997) Recruitment and post-recruitment immigration affect the local populations size of coral reef fishes. Coral Reefs 16:139-149

Manly BFJ, McDonald LL, Thomas DL (1993) Resource selection by animals. Chapman \& Hall, London

McCormick MI (2003) Consumption of coral propagules after mass spawning enhances larval quality of a damselfish through maternal effects. Oecologia 136:37-45

Munday PL (2001) Fitness consequences of habitat use and competition among coral-dwelling fishes. Oecologia 128: 585-593

Editorial responsibility: Charles Birkeland (Contributing Editor), Honolulu, Hawaii, USA
Munday PL, Jones GP, Caley MJ (1997) Habitat specialisation and the distribution and abundance of coral-dwelling gobies. Mar Ecol Prog Ser 152:227-239

Olsen CL (1976) On choosing a test statistic in multivariate analysis of variance. Psychol Bull 83:579-586

Pratchett MS, Gust N, Goby G, Klanten SO (2001) Consumption of coral propagules represents a significant trophic link between corals and reef fish. Coral Reefs 20: 13-17

Pratchett MS, Wilson SK, Berumen ML, McCormick MI (2004) Sub-lethal effects of coral bleaching on an obligate coral feeding butterflyfish. Coral Reefs 23:352-356

Pulliam HR (1974) On the theory of optimal diets. Am Nat 108: $59-75$

Reese ES (1975) A comparative field study of the social behaviour and related ecology of reef fishes of the family Chaetodontidae. Z Tierpsychol 37:37-61

Reese ES (1981) Predation on corals by fishes of the family Chaetodontidae: implications for conservation and management of coral reef ecosystems. Bull Mar Sci 31:594-604

Roberts CM, Ormond RFG (1987) Habitat complexity and coral reef fish diversity and abundance on Red Sea fringing reefs. Mar Ecol Prog Ser 41:1-6

Sale PF (1977) Maintenance of high diversity in coral reef fish communities. Am Nat 111:337-359

Sano M, Shimizu M, Nose Y (1984) Changes in the structure of coral reef fish communities by destruction of hermatypic corals: observational and experimental views. Pac Sci 38:51-79

Sano M, Shimizu M, Nose Y (1987) Long-term effects of destruction of hermatypic corals by Acanthaster planci infestation of reef fish communities at Iriomote Island, Japan. Mar Ecol Prog Ser 37:191-199

Shulman MJ (1985) Recruitment of coral reef fishes: effects of distribution of predators and shelter. Ecology 66: 1056-1066

Stephens DW, Krebs JR (1986) Foraging theory. Princeton University Press, Princeton, NJ

Syms C (1995) Multi-scale analysis of habitat association in a guild of blennioid fishes. Mar Ecol Prog Ser 125:31-43

Syms C, Jones GP (2000) Disturbances, habitat structure, and the dynamics of a coral-reef fish community. Ecology 81 : 2714-2729

Tricas TC (1989) Determinants of feeding territory size in the corallivorous butterflyfish, Chaetodon multicinctus. Anim Behav 37:830-841

Wellington GM, Victor BC (1985) El Nino mass coral mortality: a test of resource limitation in a coral reef damselfish population. Oecologia 68:15-19

Williams DM (1986) Temporal variation in the structure of reef slope fish communities (central Great Barrier Reef): short term effects of Acanthaster planci infestation. Mar Ecol Prog Ser 28:157-164

Wooten RJ (1990) Ecology of teleost fishes. Fish and fisheries series 1. Chapman \& Hall, London

Submitted: July 20, 2003; Accepted: July 28, 2004

Proofs received from author(s): January 18, 2005 